\title{
STRAIN OPTICAL ANALYSIS OF 3D PRINTING ELEMENTS IN DIFFERENT ADDITIVE TECHNOLOGIES IN COMPARISON WITH THE FINITE ELEMENT METHOD
}

\author{
Ewelina Kluska, Piotr Gruda, Natalia Majca-Nowak \\ Aviation Systems, Engineering Design Center \\ Al. Krakowska 110/114, 02-256 Warsaw, Poland \\ ewelina.kluska@ge.com, piotr.gruda@ge.com,natalia.majca@ge.com
}

\begin{abstract}
Research included in this article were conducted with a project: 'Additive technology used in conduction with optical methods for rapid prototyping of 3D printed models'. In this article intellectualized three various 3D printing technologies: Fused Deposition Modelling (FDM), Selective Laser Sintering (SLS) and Material Jetting (PolyJet). Also, there was presented theory of Digital Image Correlation (DIC) as an optical method for strain analysis. The limitations of DIC system have been tested and detected. The test result for DIC system were shown for each method of additive technologies and the results were compared to Finite Element Method (FEM). Test specimens were printed in selected technologies for reference. DIC system has been used for displacement state in loaded objects. The last paragraph contains both summary and tests results.
\end{abstract}

Keywords: Additive technology, 3D printing, digital image correlation, finite element method.

\section{INTRODUCTION}

The purpose of this article is to select the best $3 \mathrm{D}$ printing technology and a material which permit to correlate the strain optical analysis (Digital Image Correlation) with the Finite Element Method analysis.

There is still requirement to less weight construction in the aircraft structures. This demand a shape optimization and in the result components are more complicated. Although the FEM has a lot of advantages, it would be insufficient for pre-processing of the complex components after topology optimization; therefore, 3D printing technology and DIC techniques might be an alternative methods for the FEM. Nowadays both 3D printing technology and the strain optical methods are still developing, and the quality of the rapid prototyping and the optical analyses are improving.

The $3 \mathrm{D}$ printing methods which are chosen for this report are described in [1]. 


\section{DIGITAL IMAGE CORRELATION}

\subsection{DIC - theory}

Digital Image Correlation allows to maintain track of displacements on the external surfaces of the examined objects [2]. The DIC camera system required special reference points in stochastic intensity pattern to observe local movement on the external surface [3]. The surface is divided to small regions (subsets) containing $\mathrm{N} x \mathrm{~N}$ pixels [4]. The subsets dimensions depend on the quality and shape of the both surface and the stochastic intensity pattern. The DIC algorithm save every subset position during the loading test in each measurement point (index). Every subset has calculated displacement vectors $\mathrm{U}$ and V [5] (see Fig. 1.). The dedicated software converts the displacements into strains and presents a result as a colour strain map [6].

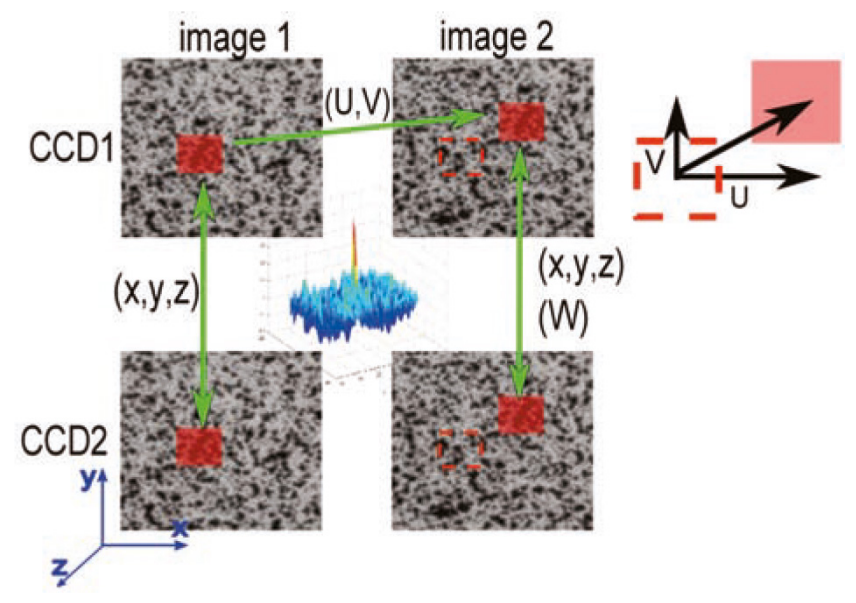

Figure 1. Simply scheme of non-deform and deform surface images analyse using

Digital Image Correlation technique [4]

\subsection{Materials}

The material appropriate for DIC and 3D printed methods should fulfil hereafter assumptions:

- high accuracy and resolution of printed models - complex shapes and thin walls are well mapped considering both rapid printing process and low price

- uniform internal structures - isotropic materials are an appropriate choice

- relatively high mechanical strength - allows to test of the 3D printed models at the generally available materials testing machine

- high impact properties which will avoid cracks or breaks of the material during a mechanical test

- homogenous material with stress-strain curve characteristic similar to metals - to compare load test results between polimer and metal

- white colour with matt surface to avoid reflex

Three materials were selected taking above requirements into consideration. The first one was the ABSplus-P430 material from the FDM technology, the second one was the VeroWhitePlus from the Material Jetting (PolyJet) technology and the last one was the Polyamide12 from the SLS technology. Material properties (manufacturer data) of these materials were gathered in the Table 1. 
Table 1. Material properties of selected materials used in the 3D printing methods (manufacturer data)

\begin{tabular}{|c|c|c|c|c|}
\hline Material properties & $\begin{array}{l}\text { Testing } \\
\text { method }\end{array}$ & $\begin{array}{c}\text { ABSplus-P430 } \\
\text { (FDM) }\end{array}$ & $\begin{array}{c}\text { VeroWhitePlus } \\
\text { (PolyJet) }\end{array}$ & $\begin{array}{l}\text { PA } 12 \\
\text { (SLS) }\end{array}$ \\
\hline Tensile strength & \multirow{4}{*}{ ASTM D638 } & $33 \mathrm{MPa}(4,8 \mathrm{ksi})$ & $58 \mathrm{MPa}(8,4 \mathrm{ksi})$ & $46 \mathrm{MPa}(6,7 \mathrm{ksi})$ \\
\hline Yield strength & & $31 \mathrm{MPa}(4,5 \mathrm{ksi})$ & - & - \\
\hline Young modulus & & $2200 \mathrm{MPa}(320 \mathrm{ksi})$ & $2500 \mathrm{MPa}(363 \mathrm{ksi})$ & $1700 \mathrm{MPa}(247 \mathrm{ksi})$ \\
\hline Elongation at break & & $6 \%$ & $10-25 \%$ & $4-15 \%$ \\
\hline Izod impact & ASTM D256 & $106 \mathrm{~J} / \mathrm{m}(2 \mathrm{ft}-\mathrm{lbs} / \mathrm{in})$ & $25 \mathrm{~J} / \mathrm{m}(0,47 \mathrm{ft}-\mathrm{lbs} / \mathrm{in})$ & $43 \mathrm{~J} / \mathrm{m}(0,8 \mathrm{ft}-\mathrm{lbs} / \mathrm{in})$ \\
\hline Flexural yield strength & \multirow{2}{*}{ ASTM D790 } & $35 \mathrm{MPa}(5 \mathrm{ksi})$ & $93 \mathrm{MPa}(13,5 \mathrm{ksi})$ & $47 \mathrm{MPa}(6,8 \mathrm{ksi})$ \\
\hline Flexural modulus & & $1650 \mathrm{MPa}(240 \mathrm{ksi})$ & $2700 \mathrm{MPa}$ (392 ksi) & $1300(189 \mathrm{ksi})$ \\
\hline
\end{tabular}

\subsection{DIC camera system limitations}

The three-dimensional specimen was subjected to a tensile testing. The stochastic intensity pattern was applied on the surface of the cylindrical specimen (see Fig. 2.) which walls had 45 degrees and right angles. The cameras were placed parallel to the right-angle walls due to check a potential of Aramis system [8]. The picture below demonstrates a view on the cameras from the Aramis System (see Fig. 3.). The test confirmed that the camera system was able to properly define a depth of focus, diameters and slop angles. The camera system was also able to clearly define a distance between the walls.

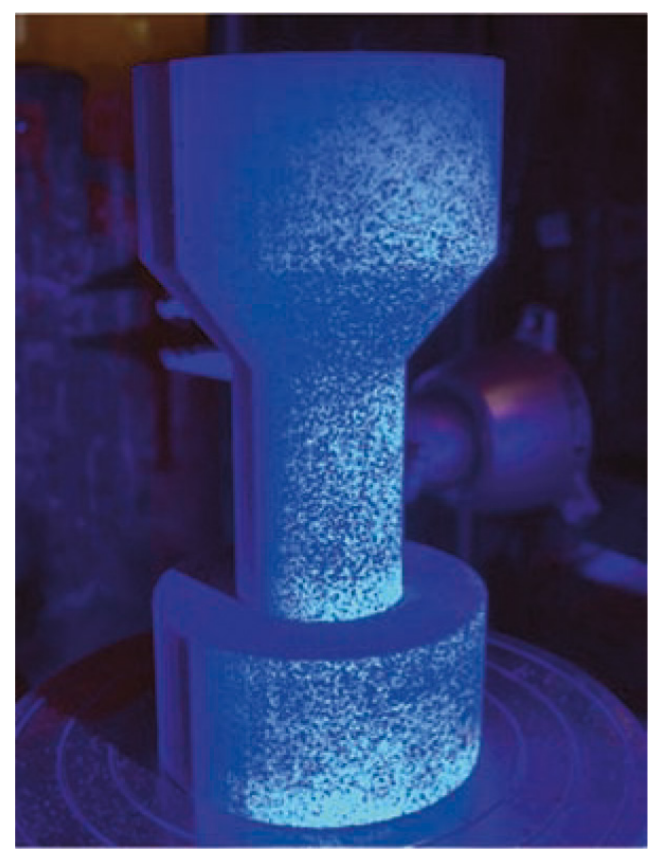

Figure 2. The three-dimensional cylinder specimen with applied of the stochastic intensity pattern on the surfaces 


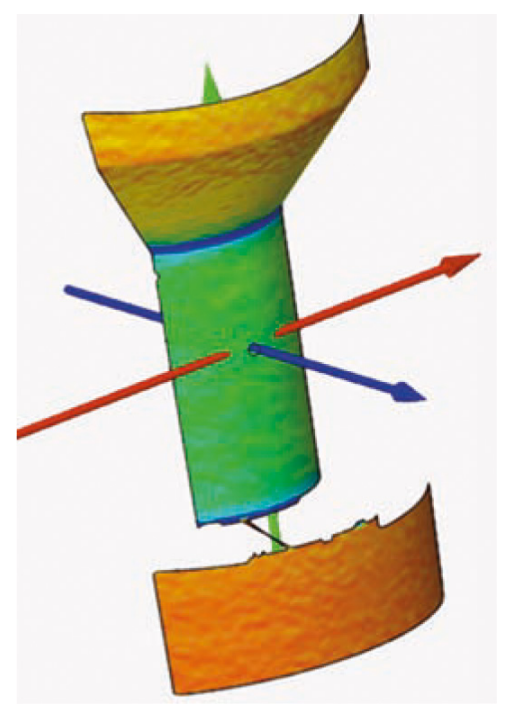

Figure 3. The view of three-dimensional cylinder specimen in the ARAMIS system - camera system placed parallel to right-angle walls

The three-dimensional bionic structure was prepared to check the potential of Aramis system with a complex shape. The stochastic intensity pattern was applied on the surfaces consist of the thin walls with empty spaces between them (see Fig. 4.) [7]. The picture below (see Fig. 5.) presents the bionic structure recorded by one camera in one measurement point (index). The internal walls of bionic structure were detected poorly by the camera system. For complete analysis should have taken several photos in various positions and the next connected them in the software or the additional camera systems should have used in the DIC test.

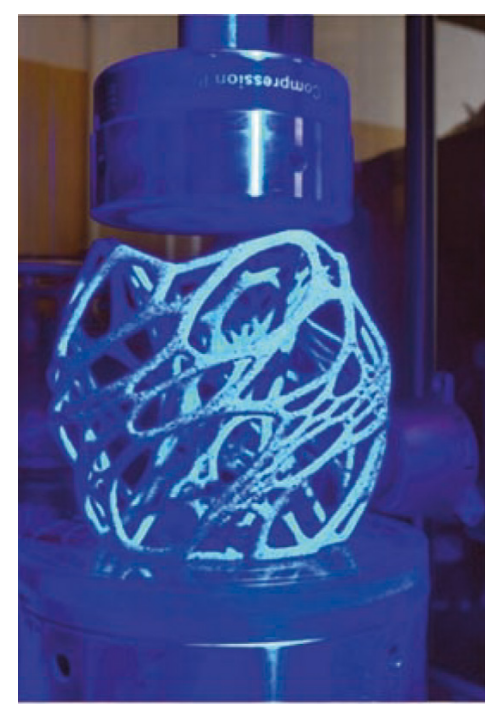

Figure 4. The three-dimensional bionic structure with applied of the stochastic intensity pattern on the walls 


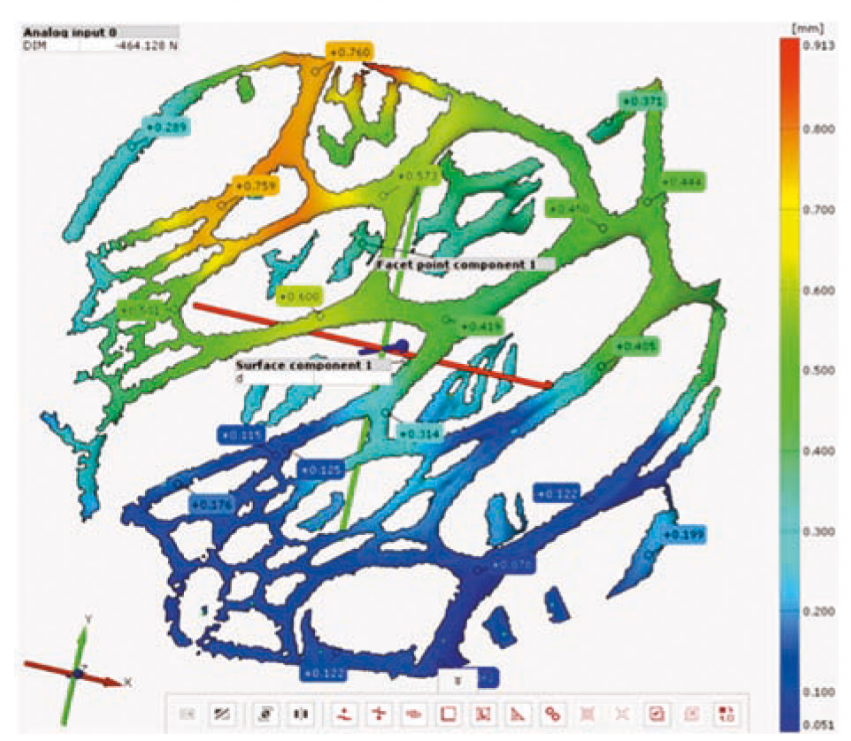

Figure 5. The view of the three-dimensional bionic structure in the ARAMIS system - view from one camera system

\section{DIGITAL IMAGE CORRELATION (DIC) TESTING}

In this chapter was checked a usability of 3D technologies for Digital Image Correlation testing [12]. The test results were conducted and demonstrated for the selected method of additive technologies: Fused Deposition Modelling (FDM), Selective Laser Sintering (SLS) and Material Jetting (PolyJet).

Each test was conducted for six specimens both three dumbbells and three rectangular prisms with hole specimens shape due to check influence of material properties and its structure on the DIC system results.

\subsection{FDM technology test results}

The first selected method was the Fused Deposition Modelling (FDM) technology [9]. Six specimens both dumbbells and rectangular prisms with hole specimens were printed from the ABSplus-P430 material on the Stratasys F370 printer. The dumbbell specimen (see Figure 6, (a)) measurements are: length: $210 \mathrm{~mm}$, thickness: $8 \mathrm{~mm}$, width: $20 / 40 \mathrm{~mm}$. The rectangular prism with hole specimen (see Figure 6, (b)) measurements are: length: $210 \mathrm{~mm}$, thickness: $8 \mathrm{~mm}$, width: $38 \mathrm{~mm}$. One surface for each specimen was coated with a chalk in the stochastic intensity pattern.

Next, for the specimens were conducted a controlled tensile testing on the MTS Landmark 370.10. machine while they were analysing by the Aramis system (DIC).

The dumbbell specimen was subjected to the tensile test until failure due to obtain a strain-stress curve (see Figure 7). Tensile strength was $29 \mathrm{MPa}$ for $2.2 \%$ strain, whereas tensile strength was $33 \mathrm{MPa}$ according to manufacturer data (Table 1)

The rectangular prism with a hole specimen was subjected to the tensile test until failure due to compare the strain-stress results between the cross section of specimen and the FEM analysis (Figure 8). 


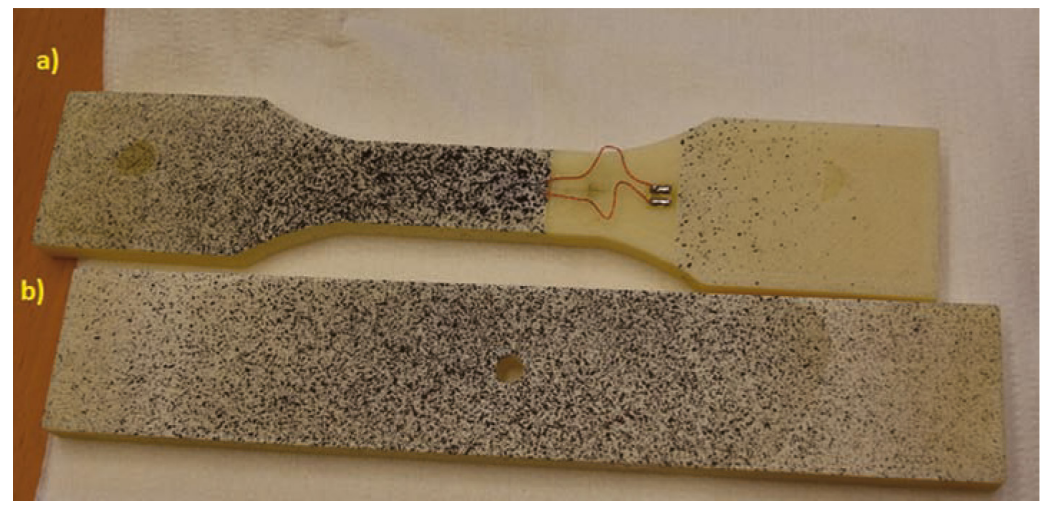

Figure 6. The real view of the dumbbell (a- length $210 \mathrm{~mm}$ ) and rectangular prism with hole (b- length $210 \mathrm{~mm}$ ) with the stochastic intensity pattern.

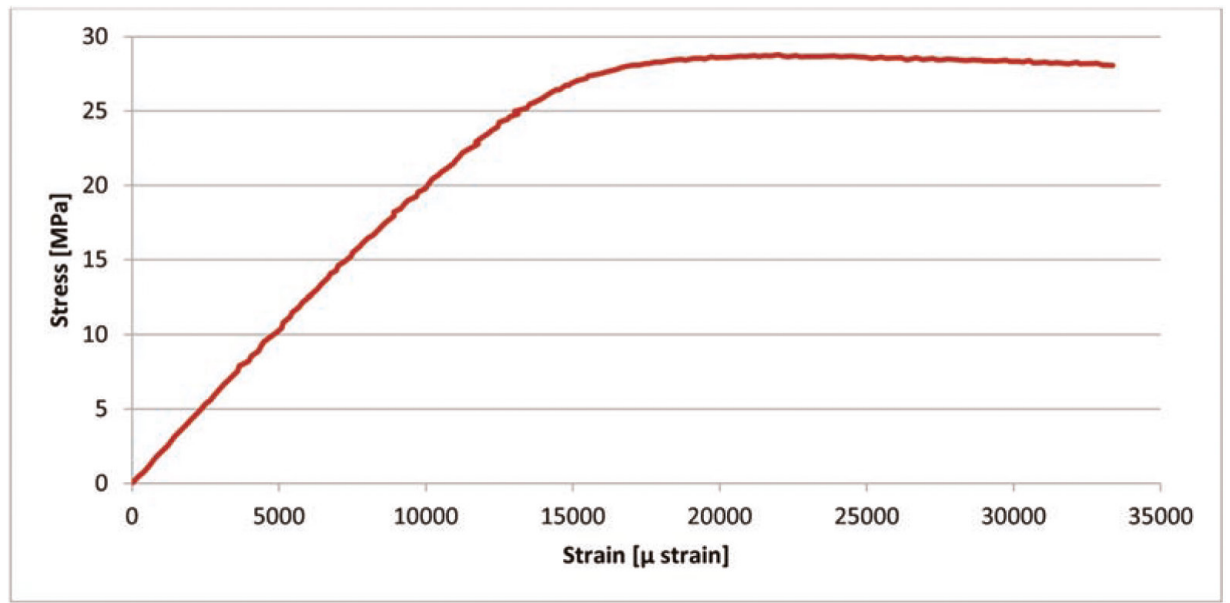

Figure 7. The strain-stress curve for ABSplus-P430 - tensile test registered for the dumbbellspecimen by the Aramis system
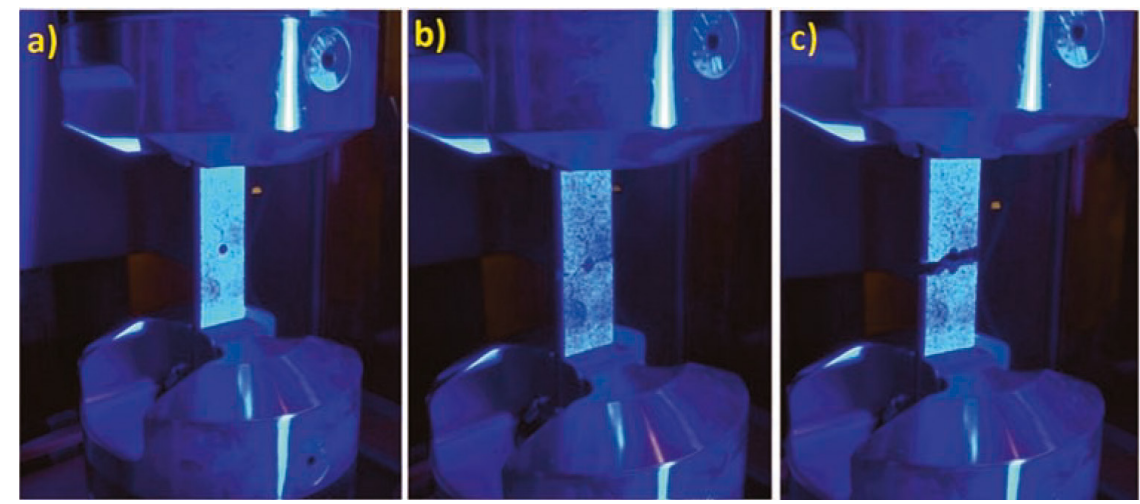

Figure 8. The rectangular prism with hole specimen mounted in the testing machine: a) during the test, both b) and c) after the test 
The DIC system were taking photos of the rectangular prism with a hole specimen during the tensile test [13]. Next, a force-time diagram was created by the Aramis software (see Figure 9). This maximum specimen force was $7361 \mathrm{~N}$.

A reference point was established to compare the strain-stress results between the cross section of specimen and the FEM analysis for one force. The reference point was $44 \%$ of the maximum specimen force to easy read in force-time diagram. A reference force was $3261 \mathrm{~N}$ for 178,60 second of the test (50 index).

The following step was created a strain diagram depends on the specimen's hole distance and conduction an analysis in the FEM software. The analyses were compared separately for linear and non-linear analyses for linear material ranges (see Figure 10 and Figure 11). The non-linear analysis is presented as Young's modulus variation against strain.

Comparing the results of strains between the Aramis software and the FEM analysis was noticed that results are concurrent above $6 \mathrm{~mm}$ from the hole. The curves convergence under $6 \mathrm{~mm}$ from the hole were able to an effect of the small strains. Furthermore, strain difference between the curves was constant on the whole distance from the hole. The exception is the edge of the hole ( 0 point), probably due to the boundary limitations of the Aramis system.

From the linear material range, the FEM linear analysis in comparison with the Aramis linear analysis is closer (Figure 10) than the FEM non-linear analysis in comparison with the Aramis non-linear analysis (Figure 11).

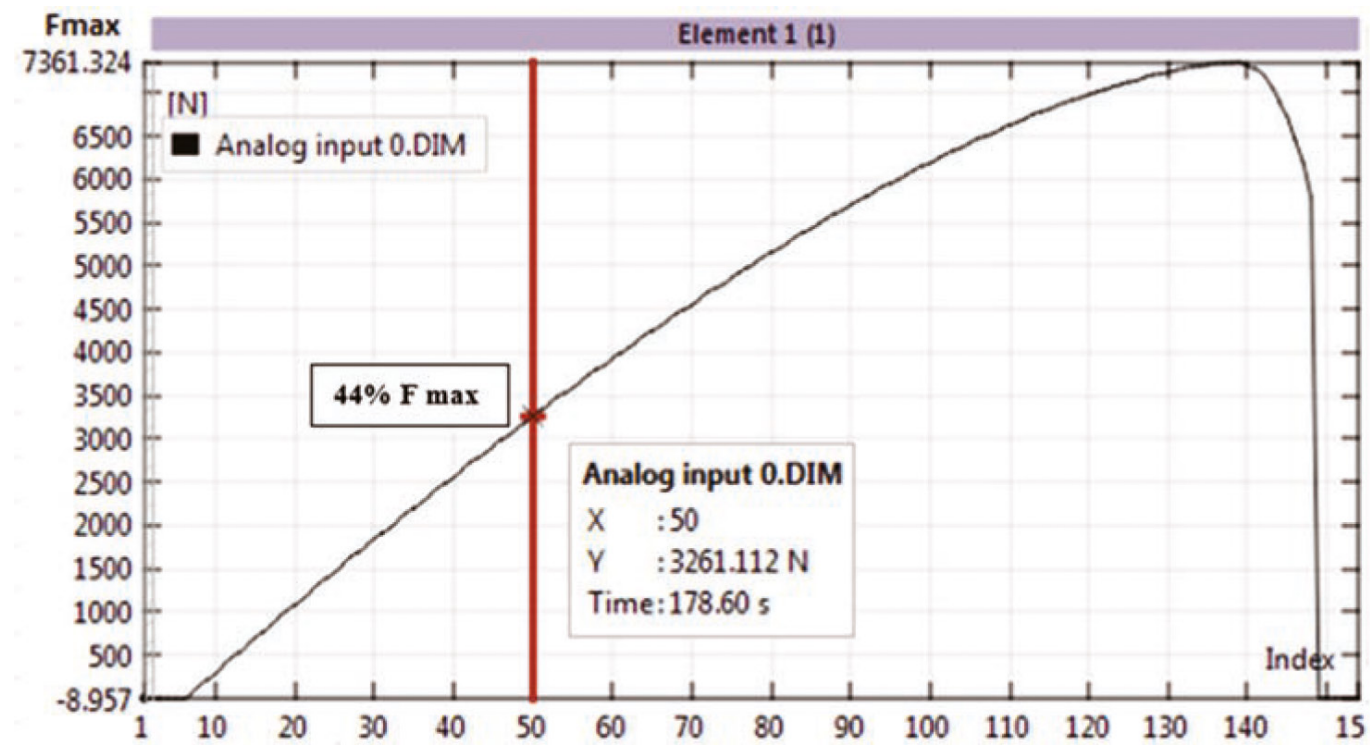

Figure 9. The force-time diagram for the tensile test for the rectangular prism with hole specimen. The reference point is indicated as a red spot 


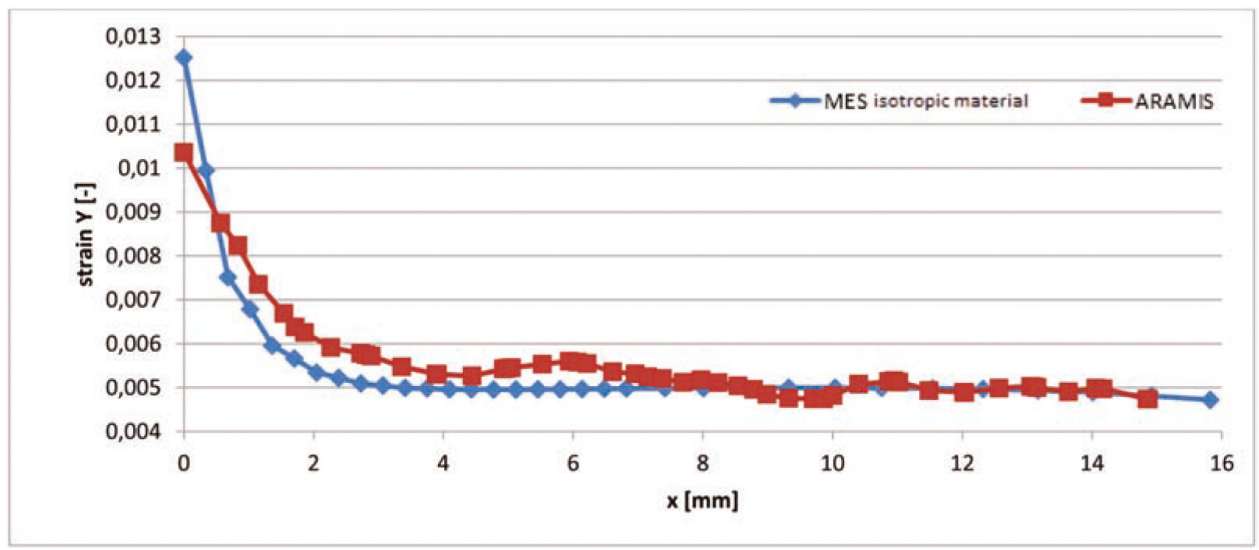

Figure 10. The strain- distance from hole curves for the reference point ( $44 \%$ of force). Linear material range, linear analysis

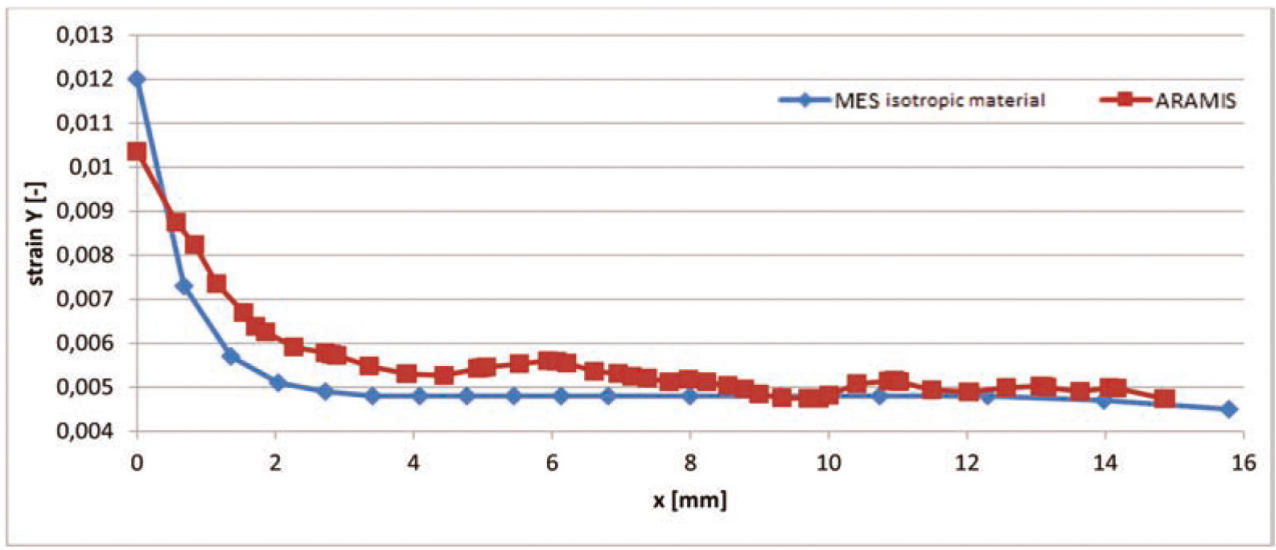

Figure 11. The strain- distance from hole curves for the reference point ( $44 \%$ of force). Linear material range, non-linear analysis

The second reference point was established to compare the strain-stress results between the cross section of specimen and the FEM analysis for non-linear material range. The reference point was $90 \%$ of the maximum specimen force to easy read in force-time diagram (see Figure 12). A reference force was $6630 \mathrm{~N}$ for 238,60 second of the test (110 index).

The analyses were compared separately for linear and non-linear analyses for non-linear material ranges (see Figure 13 and Figure 14). Comparing the results of strains between the Aramis software and the FEM analysis was noticed that results are concurrent above $7 \mathrm{~mm}$ from the hole. The curves convergence under $7 \mathrm{~mm}$ from the hole were able to an effect of the small strains. Furthermore, strain difference between the curves increase with decrease distance from the hole.

From non-linear material range, the FEM non-linear analysis in comparison with the Aramis non-linear analysis is closer (Figure 13) than the FEM linear analysis in comparison with the Aramis linear analysis (Figure 14). The results for linear material range is a bit closer between FEM and Aramis software than the results for non-linear material range between them two methods. 


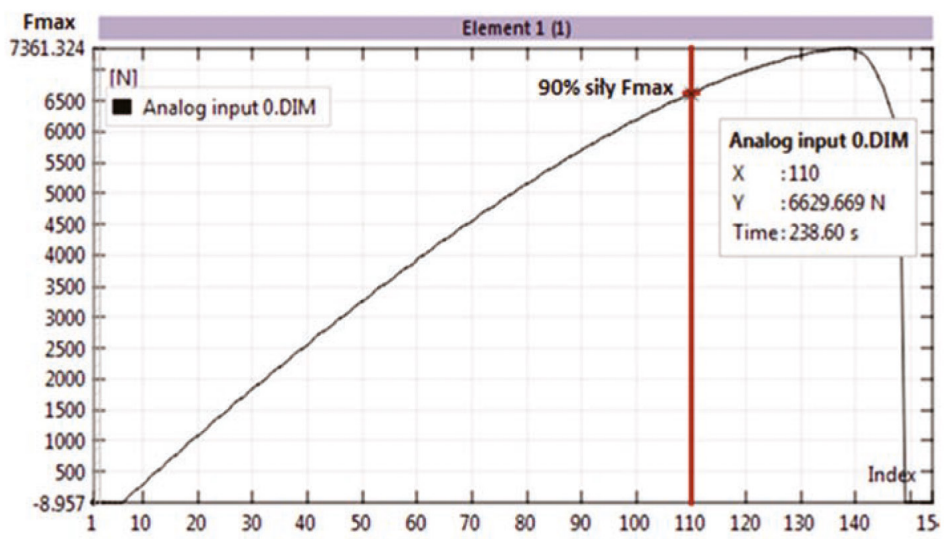

Figure 12. The force-time diagram for tensile test for the rectangular prism with hole specimen. Point indicated $90 \%$ of force is indicated as a red spot

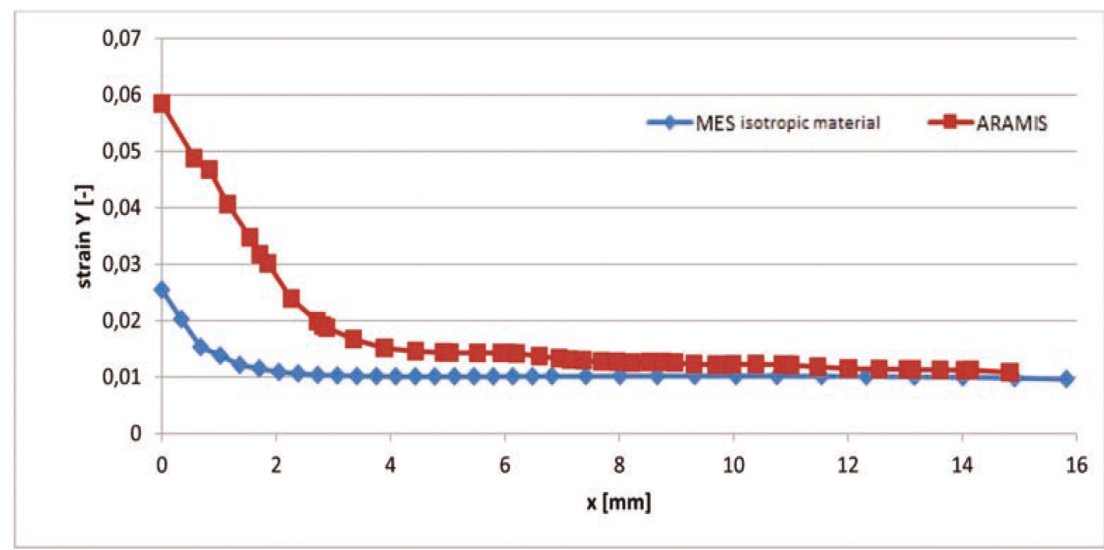

Figure 13. The strain- distance from hole curves for $90 \%$ of force. Non-linear material range, linear analysis

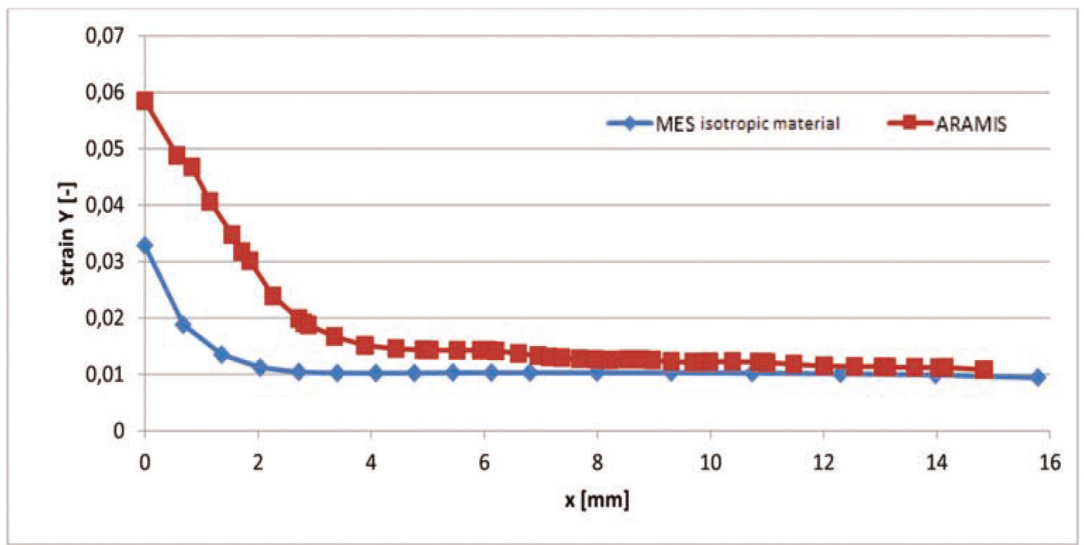

Figure 14. The strain- distance from hole curves for $90 \%$ of force.

Non-linear material range, non-linear analysis 
An orthotropic material (multilayer) was simulated in FEM analysis due to check the ABS material was characterized by similar behaviour. Figure 15 presents three curves for the reference point ( $44 \%$ of maximum force) for the linear material range and the linear analysis - first curve for the Aramis software, second curve for the FEM analysis for an isotropic material and third curve for the FEM analysis for the orthotropic material.

This diagram shows that the orthotropic material curve is far away from the Aramis software. It is stated that the ABS material used in the FDM technology has strong non-linear properties in case of the simulation was obstructed in the FEM.

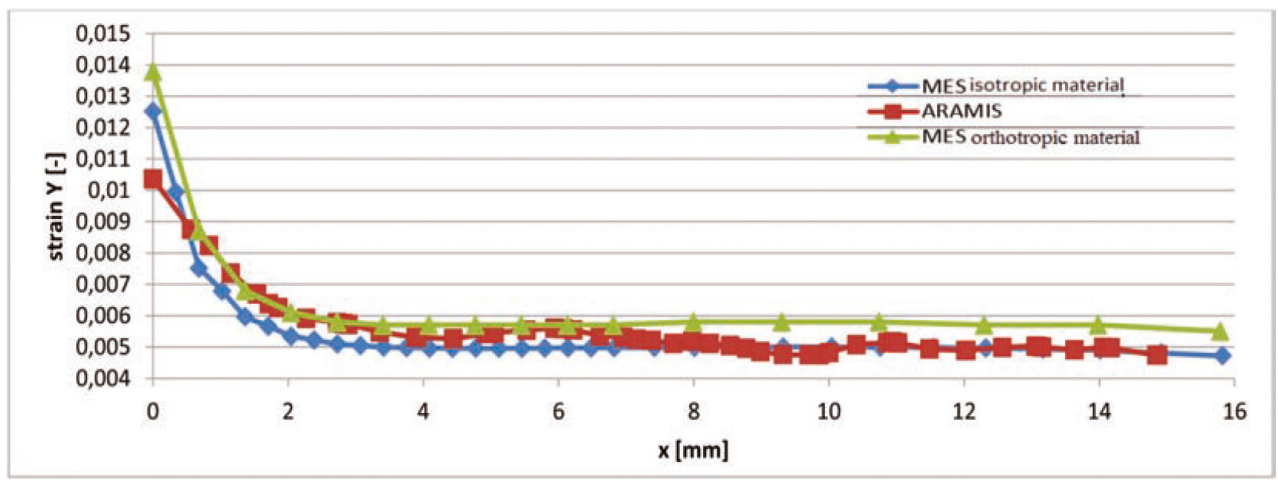

Figure 15 . The strain- distance from hole curves for $44 \%$ of force. Linear material range, linear analysis. Additional orthotropic material curve.

Hereafter are also showed strain maps for curves from Figure 15. These strain maps show the difference between strain spreading (see Figure 16).
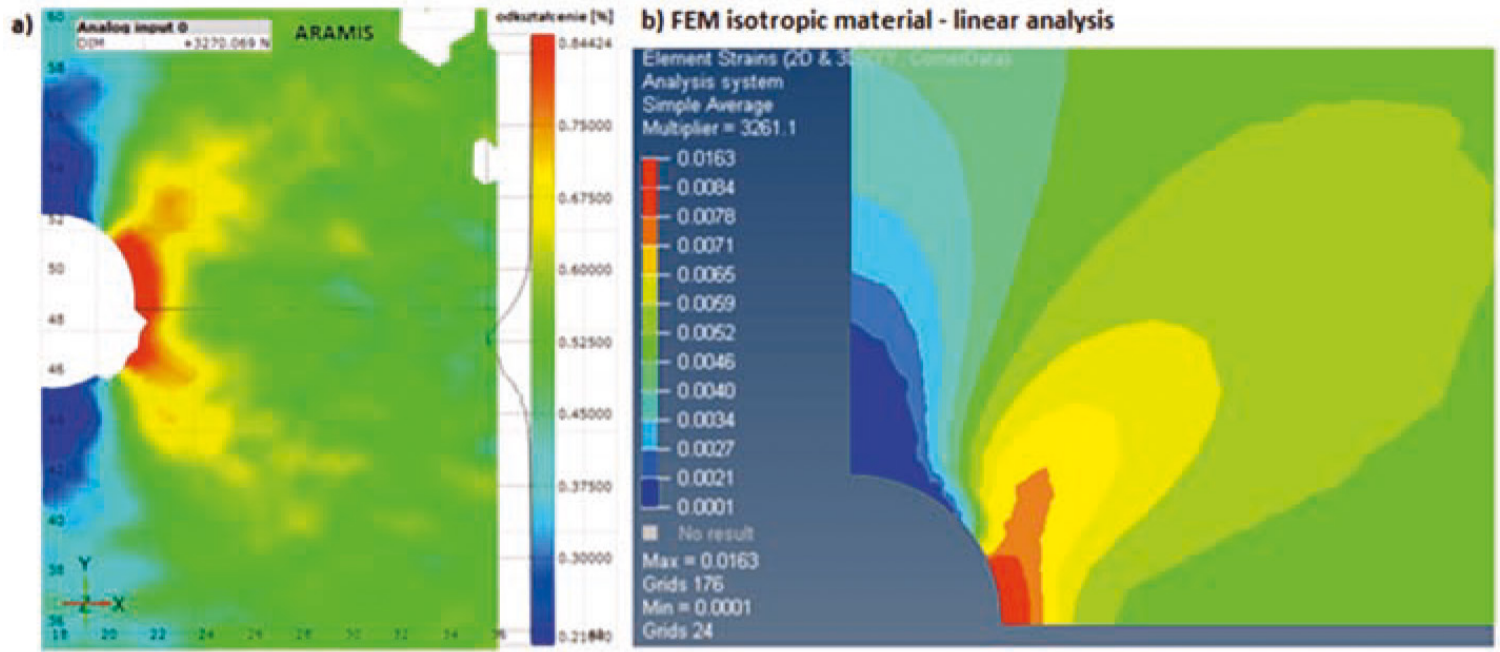


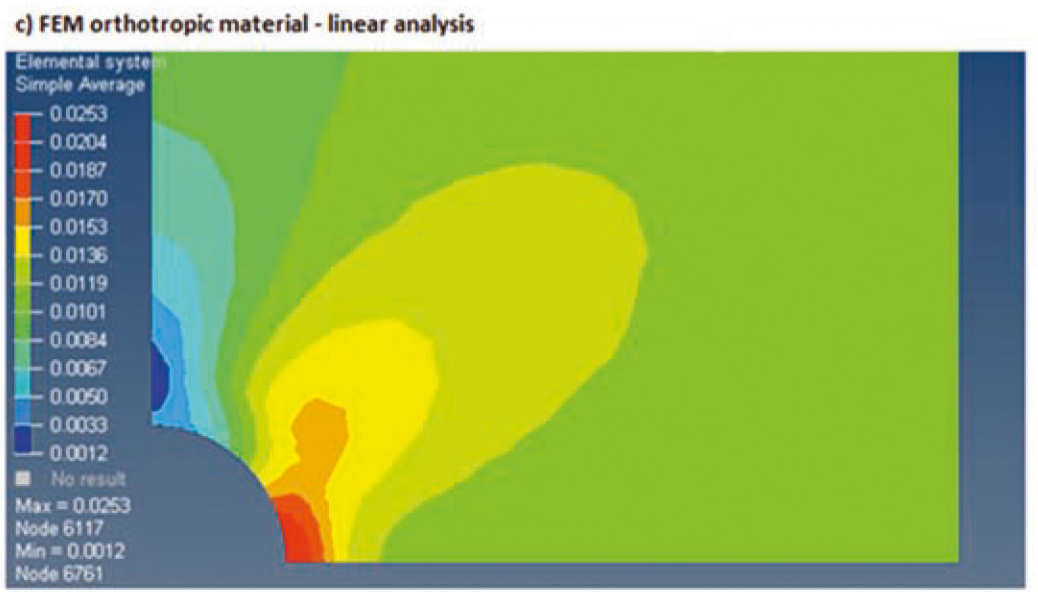

Figure 16. The strain maps for linear material range and linear analysis generated from:

a) Aramis system; b) MES - isotropic material; c) MES - orthotropic material

\subsection{SLS technology test results}

The second selected method was the Selective Laser Sintering (SLS) technology [10]. Six specimens both dumbbells and rectangular prisms with hole specimens were printed from the PA12 material material on the EOS P395 printer. The dumbbell specimen (see Figure 6, (a)) measurements are: length: $210 \mathrm{~mm}$, thickness: $8 \mathrm{~mm}$, width: $20 / 40 \mathrm{~mm}$. The rectangular prism with hole specimen (see Figure 6 , (b)) measurements are: length: $210 \mathrm{~mm}$, thickness: $8 \mathrm{~mm}$, width: $38 \mathrm{~mm}$. One surface for each specimen was coated with a chalk in the stochastic intensity pattern.

Next, for the specimens were conducted a controlled tensile testing on the MTS Landmark 370.10. machine while they were analysing by the Aramis system (DIC).

The dumbbell specimen was subjected to the tensile test until failure due to obtain a strain-stress curve (see Figure 17). Tensile strength was $50 \mathrm{MPa}$, whereas tensile strength was $46 \mathrm{MPa}$ according to manufacturer data (see Table 1

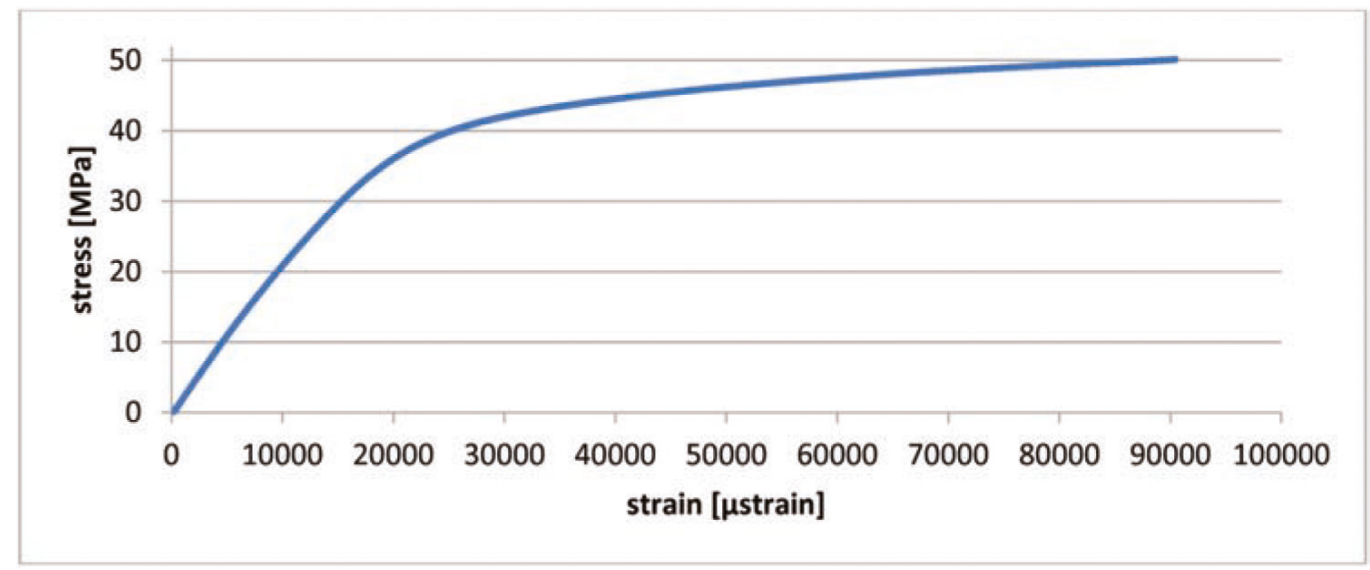

Figure 17. The strain -stress curve for PA12 - tensile test registered for the dumbbell specimen by the Aramis system 
The DIC system were taking photos of the rectangular prism with a hole specimen during the tensile test [14]. Next, a force-time diagram was created by the Aramis software (see Figure 18). This maximum specimen force was $11668 \mathrm{~N}$.

A reference point was established to compare the strain-stress results between the cross section of specimen and the FEM analysis for one force. The reference point was $43 \%$ of the maximum specimen force to easy read in force-time diagram. A reference force was $4994 \mathrm{~N}$ for 35 second of the test (8 index).

The following step was created a strain diagram depends on the specimen' s hole distance and conduction an analysis in the FEM software. The analyses were compared separately for linear and non-linear analyses for linear material ranges (see Figure 19 Figure 10 and Figure 20). The non-linear analysis is presented as Young's modulus variation against strain. Comparing the results of strains between the Aramis software and the FEM analysis was noticed that results are difference between left and right side of the hole specimen. The reason of this difference can be lack of uniform internal structure.

Furthermore, strain from the Aramis program and from the FEM analysis are divergent. The exception is a curves cross point near 0.011 strain (ca. $1 \mathrm{~mm}$ from the hole). For the linear material analysis there is no result match with the either linear or non-linear analyses.

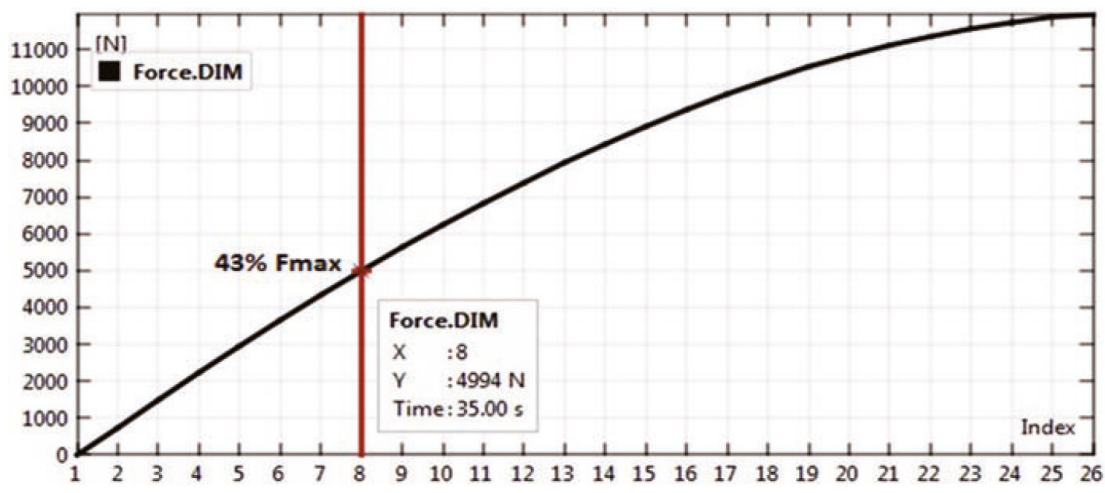

Figure 18. The force-time diagram for tension test for the rectangular prism with hole specimen.

Point indicated $43 \%$ of force is indicated as a red spot

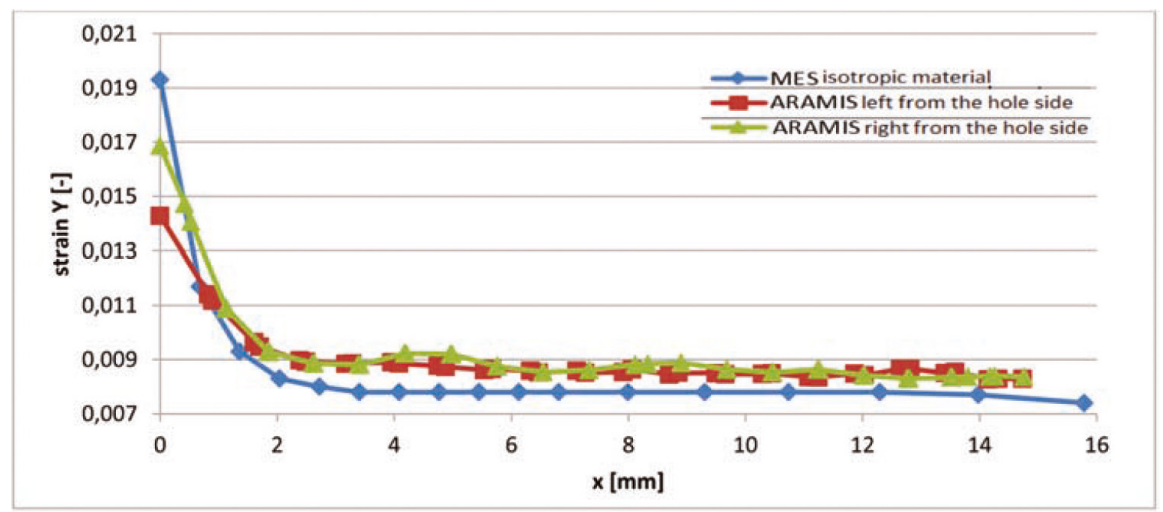

Figure 19. The strain- distance curves for $43 \%$ of the max force from the specimen' hole distance. Linear material range, linear analysis 


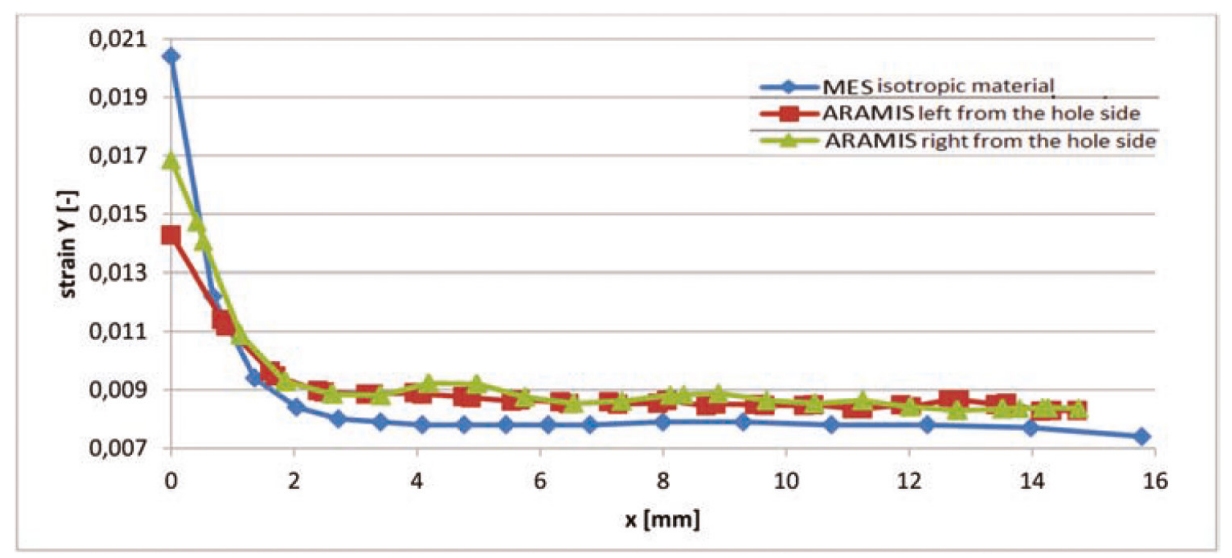

Figure 20. The strain- distance curves for $43 \%$ of the max force from the specimen' hole distance Linear material range, non-linear analysis

The second reference point was established to compare the strain-stress results between the cross section of specimen and the FEM analysis for non-linear material range. The reference point was $90 \%$ of the maximum specimen force to easy read in force-time diagram (see Figure 21). A reference force was $10533 \mathrm{~N}$ for 90 second of the test (19 index).

The analyses were compared separately for linear and non-linear analyses for non-linear material ranges (see Figure 13 and Figure 23). From non-linear material range, the FEM non-linear analysis in comparison with the Aramis non-linear analysis is closer (Figure 23) than the FEM linear analysis in comparison with the Aramis linear analysis (Figure 13). The left and right side of the hole examined specimen has divergent results under $2 \mathrm{~mm}$.

FEM non-linear analysis in non-linear material range was obtained the prime results (Figure 23) compare to other analyses for the SLS. However, FEM non-linear analysis in non-linear material range compares to the Aramis results is not enough concurrent to state the PA12 material has non-linear characteristic.

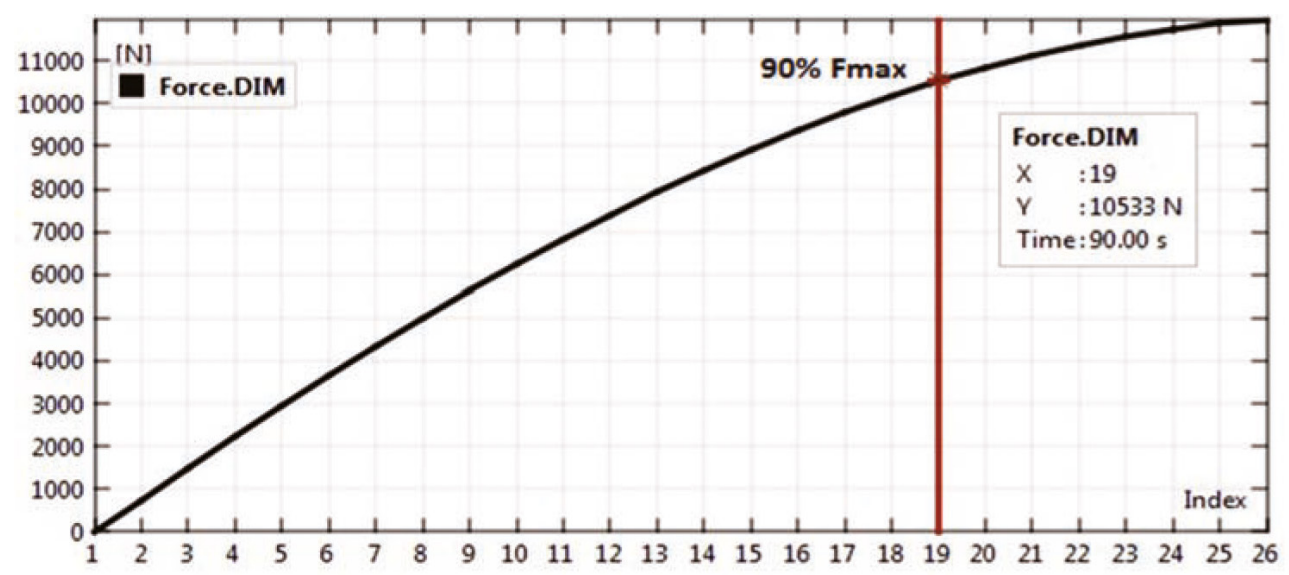

Figure 21.The force-time diagram for tension test for the rectangular prism with hole specimen. Point indicated $90 \%$ of the max force is indicated as a red spot 


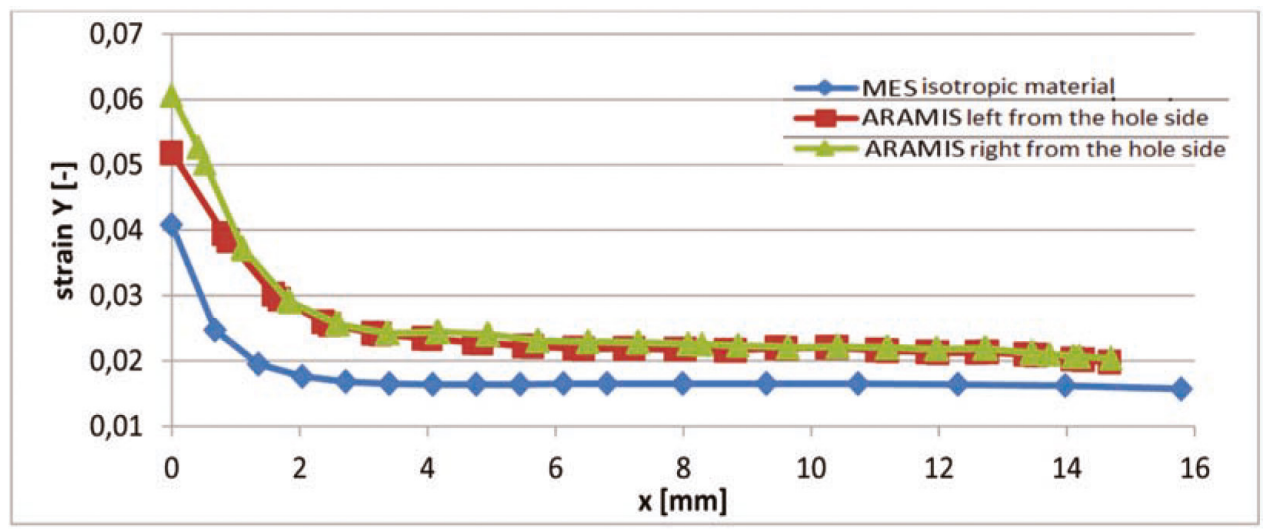

Figure 22. The strain- distance curves for $90 \%$ of the max force from distance of specimen' hole. Non-linear material range, linear analysis

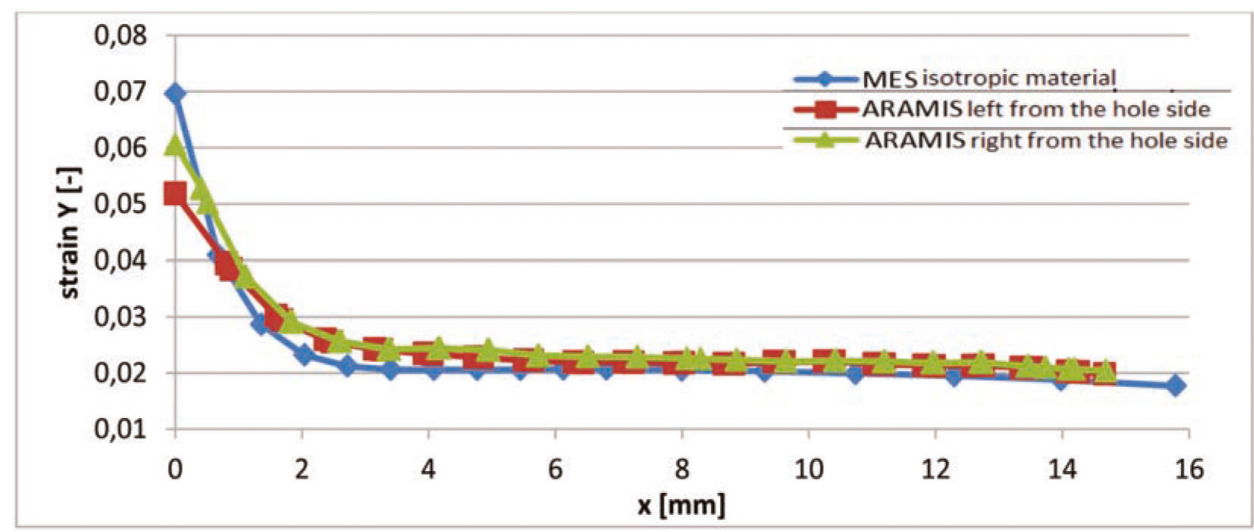

Figure 23. The strain- distance curves for $90 \%$ of the max force from distance of specimen' hole. Non-linear material range, non-linear analysis

\subsection{Material Jetting technology test results}

The final tested technology was the Material Jetting (PolyJet) [11]. Six specimens both dumbbells and rectangular prisms with hole specimens were printed from the VeroWhite Plus material on the Stratasys Objet 30 Prime printer [15]. The dumbbell specimen (see Figure 6, (a)) measurements are: length: $210 \mathrm{~mm}$, thickness: $8 \mathrm{~mm}$, width: $20 / 40 \mathrm{~mm}$. The rectangular prism with hole specimen (see Figure 6, (b)) measurements are: length: $210 \mathrm{~mm}$, thickness: $8 \mathrm{~mm}$, width: $38 \mathrm{~mm}$. One surface for each specimen was coated with a chalk in the stochastic intensity pattern.

Next, for the specimens were conducted a controlled tensile testing on the MTS Landmark 370.10. machine while they were analysing by the Aramis system (DIC).

The dumbbell specimen was subjected to the tensile test until failure due to obtain a strain-stress curve (see Fig. 24., Fig. 7). Tensile strength was $48 \mathrm{MPa}$, whereas tensile strength was $58 \mathrm{MPa}$ according to manufacturer data (see Table 1).

The rectangular prism with a hole specimen was subjected to the tensile test until failure due to compare the strain-stress results between the cross section of specimen and the FEM analysis. 


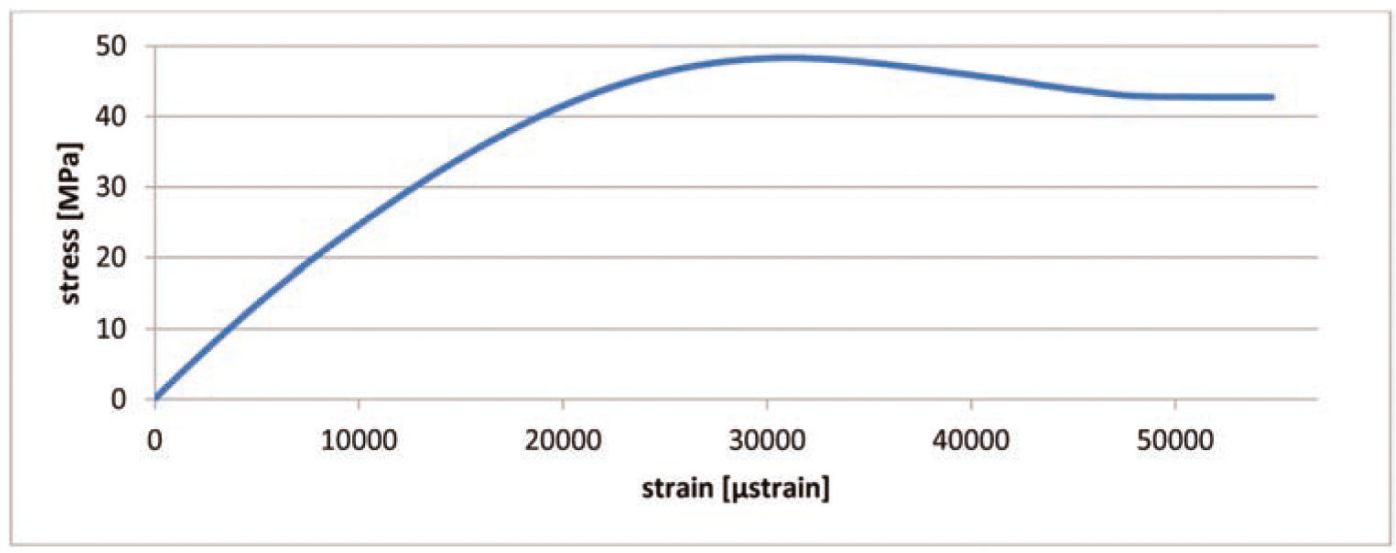

Figure 24. The strain -stress curve for VeroWhite Plus - the dumbbell specimen test register by the Aramis system

The DIC system were taking photos of the rectangular prism with a hole specimen during the tensile test. Next, a force-time diagram was created by the Aramis software (see Figure 25). This maximum specimen force was $13538 \mathrm{~N}$.

A reference point was established to compare the strain-stress results between the cross section of specimen and the FEM analysis for one force. The reference point was $42 \%$ of the maximum specimen force to easy read in force-time diagram. A reference force was $5706 \mathrm{~N}$ for 33 second of the test (12 index).

The following step was created a strain diagram depends on the specimen's hole distance and conduction an analysis in the FEM software. The analyses were compared separately for linear and non-linear analyses for linear material ranges (see Figure 26 and Figure 27). The non-linear analysis is presented as Young's modulus variation against strain.

Comparing the results of strains between the Aramis software and the FEM analysis were diverged from the left and right side of the specimen's hole under $1 \mathrm{~mm}$. From the linear material range, comparing the results of the non-linear analyses between the FEM analyses and the Aramis software are closer than comparing the results of linear analyses between them.

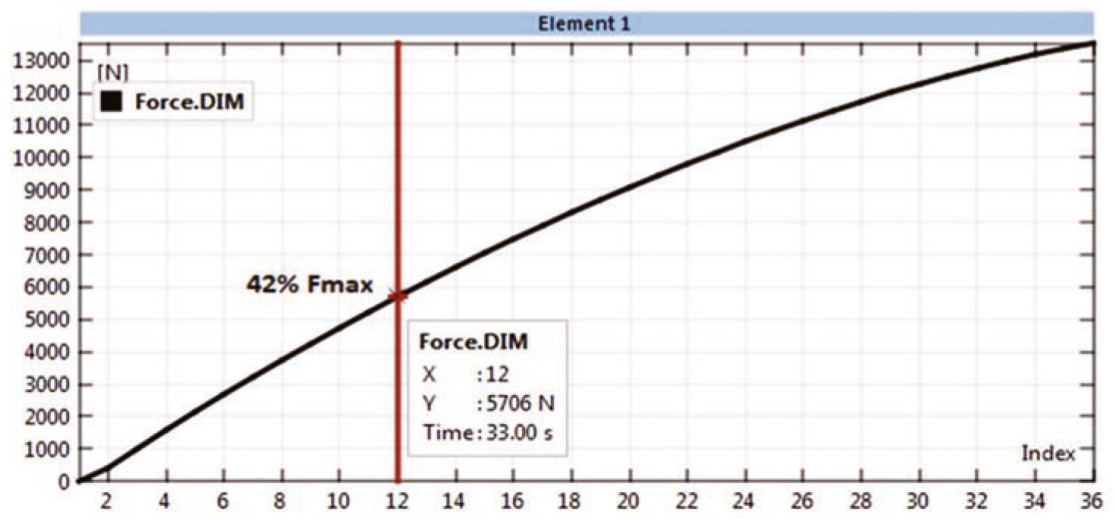

Figure 25. The force-time diagram for tension test for the rectangular prism with hole specimen. Point indicated $42 \%$ of force is indicated as a red spot 


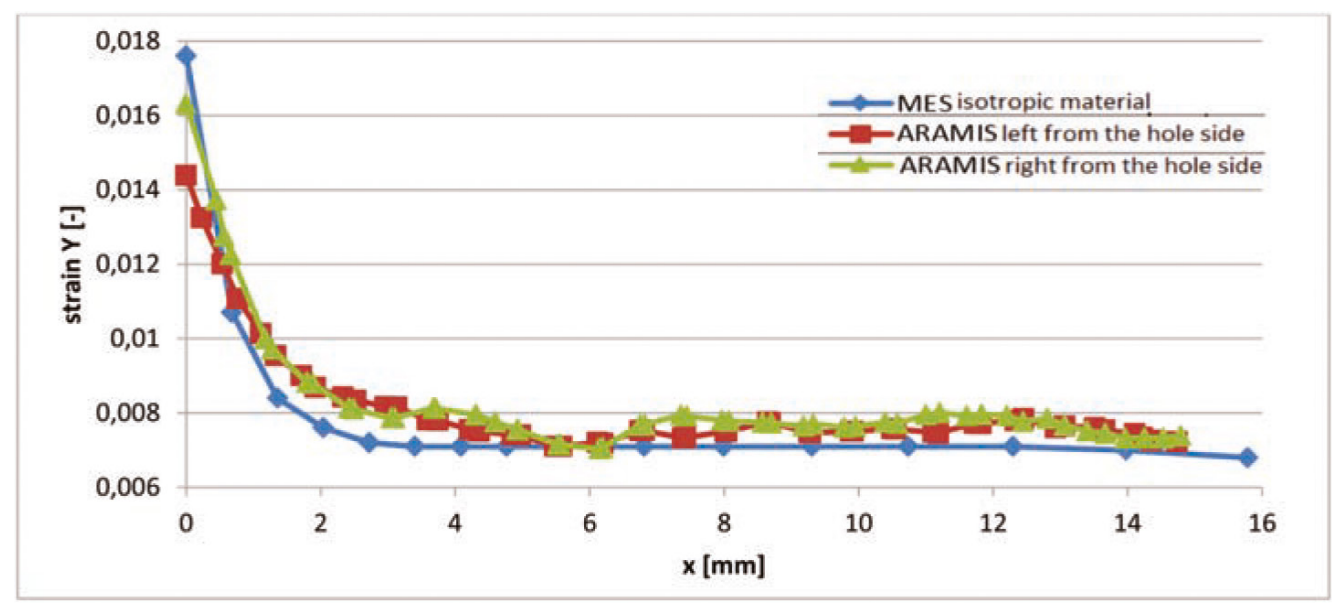

Figure 26. The strain- distance curves for $42 \%$ of the max force from the specimen' hole distance. Linear material range, linear analysis

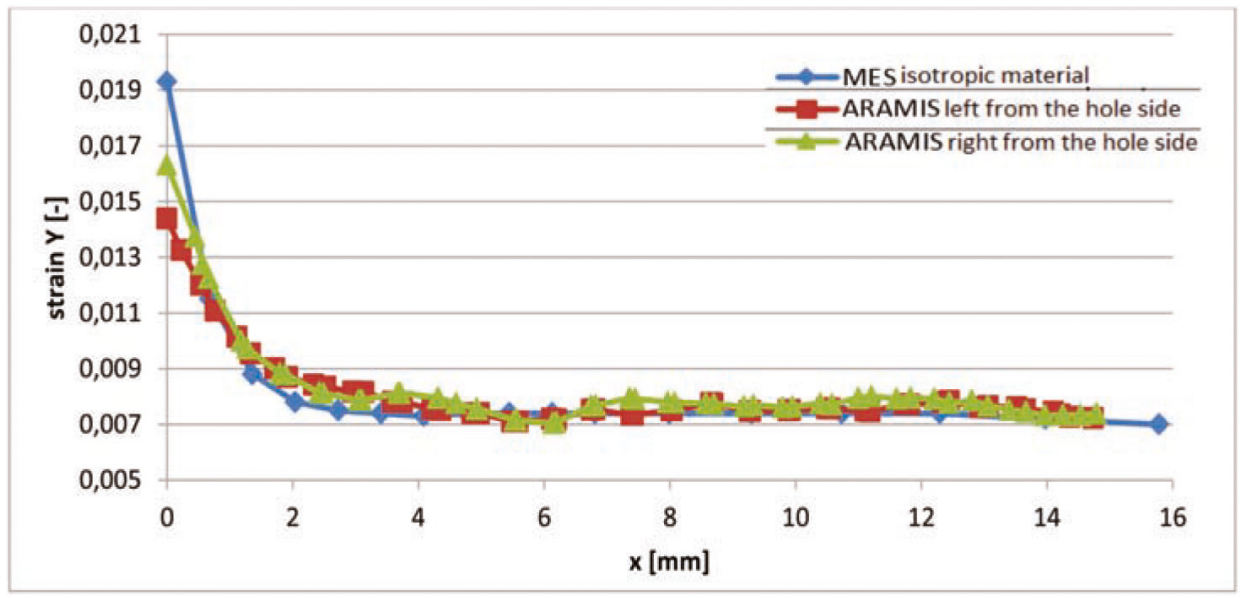

Figure 27 . The strain- distance curves for $42 \%$ of the max force from the specimen' hole distance. Linear material range, non-linear analysis

The second reference point was established to compare the strain-stress results between the cross section of specimen and the FEM analysis for non-linear material range. The reference point was $91 \%$ of the maximum specimen force to easy read in force-time diagram (see Figure 28). A reference force was $12269 \mathrm{~N}$ for 87 second of the test (30 index).

The analyses were compared separately for linear and non-linear analyses for non-linear material ranges (see Fig. 13 and Fig. 30.). Comparing the results of strains between the Aramis software and the FEM analysis were diverged from the left and right side of the specimen's hole under $1 \mathrm{~mm}$.

Figure 30 demonstrates non-linear analyses for non-linear material range where Aramis software results are similar to the FEM analysis above $2 \mathrm{~mm}$ from the specimen's hole.

The results for non- linear material range for Material Jetting technology were the most suitable result for the FEM analyses. 


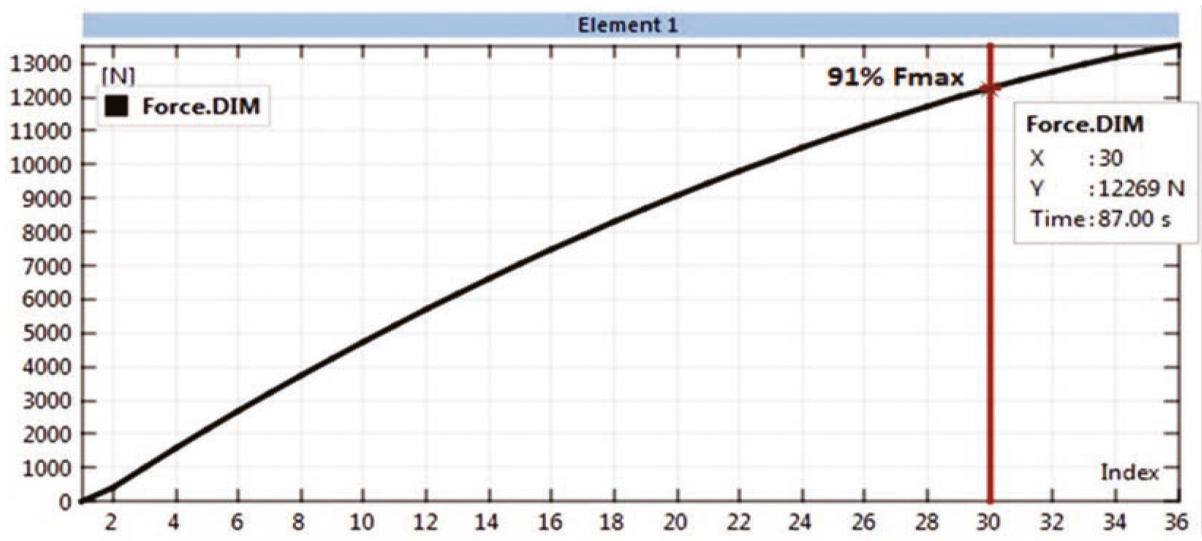

Figure 28. The force-time diagram for tension test for the rectangular prism with hole specimen. Point indicated $91 \%$ of force is indicated as a red spot

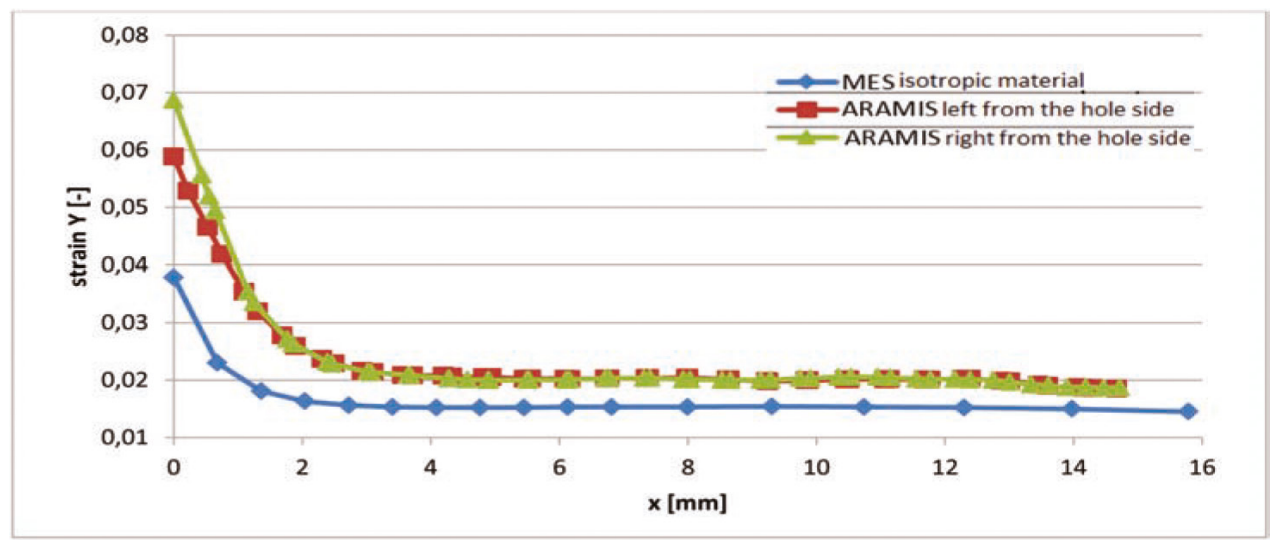

Figure 29. The strain- distance curves for $91 \%$ of the max force from distance of specimen' hole. Non-linear material range, linear analysis

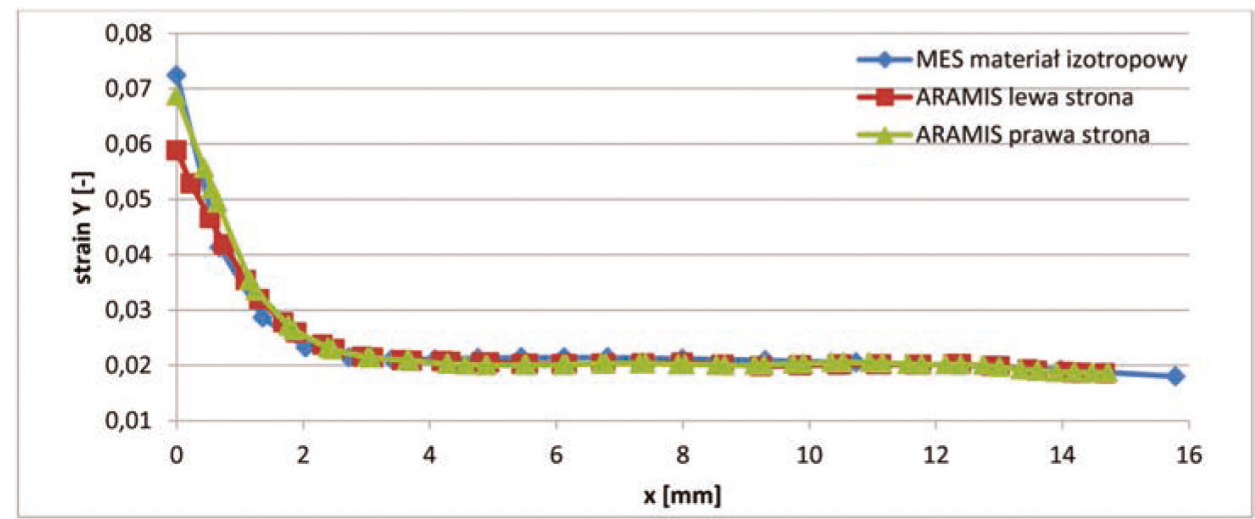

Figure 30. The strain- distance curves for $91 \%$ of the max force from distance of specimen' hole. Non-linear material range, non-linear analysis 


\section{SUMMARY}

The primary purpose of this article was to select the appropriate 3D printing technology to correlate the results in tensile test between the Digital Image Correlation (DIC) and Finite Element Method (FEM) analysis. Moreover, the selected method should obtain the final models in rapid and simply technique. The 3D printing technologies were specified considering print parameters and material availability - FDM, SLS and PolyJet. The revision was created in particular to analyse of complicated shapes by the best parameters for each $3 \mathrm{D}$ printing method for the accessible printing machine; therefore, for printing process were used the minimal thickness of layers for each method for the concrete $3 \mathrm{~d}$ printing machine (not the same thickness for all). The stair effect is unmentioned due to ensure smooth surfaces by using the minimal thickness of printing layer [16].

Specimens printed in the listed 3D technologies were used for the DIC system test by the Aramis software. The DIC system was subjected to an optical constrains verification. It was evidenced that DIC cameras registered properly diameters, slop angles and the depth of focus, though one snapshot of one camera system was not able to create a complete $3 \mathrm{D}$ image of complex component.

Furthermore, the specimens were subjected to the tensile test and stress-strain results from the Aramis software were compared with the FEM analyses. It was revealed that the DIC system subjects to a nonhomogeneous structure of material such as pores or material texture; therefore, the DIC system need to find the most homogenous structure of material.

The FDM technology with the ABS Plus-P430 material was excluded due to the high nonhomogeneous structure of material and porosity; therefore, the results comparing between FEM analysis and Aramis software was obstructed.

The SLS technology with the PA12 material was occurred in excess of the material's porosity; therefore, the results comparing between FEM analysis and Aramis software was omitted.

The PolyJet technology with the VeroWhite Plus material was characterized by virtually homogenous structure in consequence, the results between Aramis software (DIC) and the FEM analysis are similar for non-linear analysis in non-linear material range. Nevertheless, the VeroWhite Plus material displayed an isotropic characteristic however only in non-linear material range.

In summary, the investigation demonstrated in this article allowed to type the optimal $3 \mathrm{D}$ printing technology for DIC test. However, it is needed to conduct another investigation to find the material with isotropic characteristic in linear material range due to compare DIC technique and the FEM analysis in whole material range.

\section{BIBLIOGRAPHY}

[1] Kluska E., Gruda P. The accuracy and the printing resolution comparison of different 3D printing technologies. Warsaw: Institute of Aviation, 2017.

[2] MESOCOS. DIC Measurements in Engineering Applications. [Online] http://image-correlation.com/assets/files/MESOCOS-DIC.pdf.

[3] Chu T.C., Ranson W.F., Sutton M.A, Peters W.H. Application of digital-image-correlation techniques to experimental mechanics. Experimental Mechanics. 1985, 25(3), 232-244.

[4] Lutowski Z., Marciniak B., Marciniak T., Bujnowski S. Precision of sub-pixel image displacement measurements. Journal of Machine Construction and Maintenance. 107, 4/2017, ISSN 1232-9312.

[5] Brebbia C.A., Klemm A. Digital Image Correlation set-up. Materials characterisation VI: Computational Methods and Experiments. Southampton: WIT Press, 2013. 
[6] Saouma V., Cintron R. Strain Measurements with the Digital Image Correlation System Vic-2D. Mayaguez: University of Puerto Rico, 2008.

[7] Amir M.Mirzendehdel, Krishnan Suresh, A Hands-on Introduction to Topology Optimization, Paperback, Academic Press, September 2017.

[8] D. Chambers, Digital Image Correlation: Advanced Methods and Applications (Materials Science and Technologies), Nova Science Pub Inc, June 2017.

[9] Bibus Menos - FDM, PolyJet, SLS, DMLS - technology, materials,3d printers. [Online] https:// www.bibusmenos.pl/oferta/drukarki-3d/.

[10] CadXpert - 3d printing technology and printer in FDM, SLA, SLS and Material Jetting. [Online] http://www.cadxpert.com.pl/.

[11] Rabbit Form - Article about 3D printing. [Online] http://www.rabbitform.pl/category/artykuly/.

[12] GOM Application example: Material testing; Material properties: Improved Determination of yield stress for sheet metal materials. [Online] www.lenso.com.pl/.

[13] KSMVision - The article about Digital Image Correlation - optical measurements. [Online] http://ksmvision.pl/cyfrowa-korelacja-obrazu/.

[14] Burzyńska-Szkoda K. Analysis of the displacements and deformations recorded with the use of Digital Image Correlation on the surfaces of selected machine elements [Online] www.biomech.pwr.wroc. $\mathrm{pl} /$.../Instrukcja-ćwiczenie-1-cyfrowa-korelacja-obrazu-1.pdf.

[15] The 3D printing is more accurate than you think. [Online] HYPERLINK "http://swiatdruku3d.pl/ druk-3d-dokladniejszy-niz-myslisz/?_sm_nck=1" http://swiatdruku3d.pl/druk-3d-dokladniejszyniz-myslisz/?_sm_nck=1 .

[16] Make beautiful 3D prints understanding the layer thickness. [Online] https://www.sculpteo.com/ blog/2015/07/29/make- beautiful-3d-prints-understanding-the-layer-thickness/

\section{OPTYCZNA ANALIZA ODKSZTAŁCEŃ ELEMENTÓW WYDRUKOWANYCH 3D W WYBRANYCH TECHNOLOGIACH PRZYROSTOWYCH W PORÓWNANIU DO METODY ELEMENTÓW SKOŃCZONYCH}

\section{Streszczenie}

W niniejszym artykule przedstawiono prace wykonane w ramach projektu „Wykorzystanie metod druku 3D (rapid prototyping) w połączeniu z badaniami optycznymi do szybkiego optymalizowania przestrzennych modeli wykonanych w technologii przyrostowej”. Artykuł rozpoczyna się od przedstawienia trzech wybranych technologii drukowania 3D: Fused Deposition Modeling (FDM), Selective Laser Sintering (SLS) oraz Material Jetting(PolyJet). W wybranych technologiach zostały wydrukowane testowe próbki referencyjne. Następnie opisano teorię dotyczącą cyfrowej korelacji obrazu DIC jako optycznej metody analizy odkształceń. W pracy przedstawiono wyniki testowania 
wybranych technologii druku 3D za pomocą systemu cyfrowej korelacji obrazu w porównaniu do metody elementów skończonych MES. Przetestowano również ograniczenia systemu DIC. Cyfrowa korelacja obrazu użyta jest do analizy stanu przemieszczeń w rzeczywistych obiektach poddanych obciążeniu. Artykuł zakończono podsumowaniem zawierającym wnioski oraz omówienie otrzymanych wyników.

Słowa kluczowe: druk 3D, cyfrowa korelacja obrazu, metoda elementów skończonych. 